\title{
Inhibitory Effect of Egyptian Garlic Extract on Penicillic Acid Production
}

\author{
A. A. Ismaiel \\ Department of Botany, Faculty of Science, Zagazig University, \\ Zagazig, Egypt.
}

\begin{abstract}
7 HE INHIBITORY effects of aqueous Egyptian garlic extract on growth and penicillic acid production of Penicillium hirsutum were established. Minimal inhibitory concentration (MIC) of the aqueous garlic extract was determined by the agar diffusion assay, which was $30 \mathrm{mg} / \mathrm{ml}$. Growth of the fungus in broth containing higher concentrations of garlic extract ( 18 and $24 \mathrm{mg} / \mathrm{ml}$ ) showed that sporulation was completely inhibited after 7 days of incubation or became very slight after 10 days at these mentioned concentrations. The increase in garlic concentration caused a gradual increase in the average values of mycelial dry weights reaching a maximum at $24 \mathrm{mg} / \mathrm{ml}$. In the contrary, the increase in garlic extract concentration induced a reduction in the levels of penicillic acid production. The amount of penicillic acid in presence of $24 \mathrm{mg} / \mathrm{ml}$ of garlic was approximately $44 \%$ that of control culture filtrate after 10 days of incubation, however penicillic acid was not detected completely at the same garlic extract concentration after 7 days of incubation. This study was also extended to analyze and evaluate the percentage of the main components in garlic extract that may be responsible for these inhibitory effects, applying GC-MS chromatographic analysis. This is the first report on the inhibition of penicillic acid production by a natural substance as garlic extract.
\end{abstract}

Keywords: Garlic, Mycotoxins, Penicillic acid, Antifungal activity, Penicillium hirsutum.

Over the years much efforts have been devoted to the search for new antifungal materials from natural sources for food preservation (Onyeagba et al., 2004 and Haciseferogullari et al., 2005). Among the natural fungicidal substances, garlic extract has been found to be active in various trials (Yoshida et al.,1987; Tariq \& Magee, 1990; Ghahfarokhi et al., 2003 and Irkin \& Korukluoglu, 2007). Moreover, aflatoxin production by Aspergillus parasiticus and keratinolytic activity of Trichophyton mentagrophytes, were reported to be inhibited by the use of garlic (Graham \& Graham, 1987 and Ghahfarokhi et al., 2003).

Among the toxigenic fungi, P.hirsutum, is a frequent contaminant of different food products, flower and vegetable bulbs and seems to be common, widespread species occurring in storage and is known to produce a variety of secondary toxic metabolites (Frisvad, 1981; Frisvad \& Samson, 2004; Satio et al., 2004 and Overy et al., 2005) including penicillic acid (Frisvad \& Filtenborg, 1983; Ezzat et al., 2007 
and Ismaiel, 2007). The hazardous effects and carcinogenic nature of penicillic acid made it a cause of concern (Palmgren \& Ciegler, 1983; Wannemacher et al., 1991; Macri et al., 2002 and He et al., 2004). The potential risk of penicillic acid for human health was suggested when penicillic acid had been isolated from agricultural products such as poultry feed, blue eye diseased corn, commercial corn, dried beans and tobacco products (Kurtzman \& Ciegler, 1970; Pero et al., 1972 and Thrope \& Johnson, 1974) and from mold-fermented sausage (Ciegler et al., 1972).

In spite of reports on the antifungal activity of garlic (Graham \& Graham, 1987; Ghahfarokhi et al., 2003 and Irkin \& Korukluoglu, 2007) and inhibition of penicillic acid production by many chemicals (Lari \& Thomas, 1980; Gourama \& Bullerman, 1988 and Garza et al., 1993), no data have appeared on the effect of garlic on the production of this toxin.

\section{Material and Methods}

\section{Materials}

Garlic bulbs

Fresh garlic (Allium sativum L.): bulbs were purchased from a local supermarket in Zagazig town, Egypt.

\section{Microorganism}

$P$. hirsutum has been isolated from a local sample of paddy rice grains and was found to produce the mycotoxin, penicillic acid. It was identified to the species level according to Frisvad \& Samson (2004).

\section{Culture media}

Czapek-Dox`s agar supplemented with $0.5 \%$ (w/v) yeast extract (Kurtzman \& Ciegler, 1970) used for maintaining and culturing of the fungus during the determination of the antifungal activity tests and the MIC of garlic extract.

Modified Raulin-Thom broth, containing $0.07 \%(\mathrm{w} / \mathrm{v}) \mathrm{Na}_{2} \mathrm{HPO}_{4}$ in equimolecular weight to the original phosphorus source $\left(\mathrm{NH}_{4}\right)_{2} \mathrm{HPO}_{4}$ in the Raulin-Thom broth (Bentley \& Keil, 1962 and Lindenfelser \& Ciegler, 1977), was the most preferable during a previous screening study for selection of the optimum fermentation medium for maximum penicillic acid production by P. hirsutum (Ismaiel, 2007).

\section{Methods}

Preparation of the aqueous garlic extracts

This was adopted according to Curtis et al. (2004) and Bakri \& Douglas (2005). Garlic bulbs were peeled and washed several times. The fresh garlic cloves $(255 \mathrm{~g}$ ) were blended in $255 \mathrm{ml}$ distilled water, and homogenized in a domestic juicer (Braun Combimax 700 Vital, Germany) for $3 \mathrm{~min}$ at average speed to extract the juice. The juice was then centrifuged at $3000 \mathrm{rpm}$ for $10 \mathrm{~min}$. The precipitated material was weighted and the supernatant was filtered through Whatman no.1 filter paper and the resulting filtrate was then filter sterilized by 
passing through a $0.45 \mu \mathrm{m}$ cellulose nitrate membrane filter. By subtracting the weight of the insoluble material from the weight of the original cloves, the final concentration of the garlic extract in solution was determined. The garlic extract was used immediately or stored at $4^{\circ} \mathrm{C}$ until used.

Antifungal activity tests

MIC determination : Sensitivity of the fungus to garlic extract concentrations $(30,60,120,240,360,480,540$ and $600 \mathrm{mg} / \mathrm{ml})$ was determined by inoculating sterile Petri-dishes with $0.2 \mathrm{ml}$ fungal suspension contain approximately $10^{6}$ spores $/ \mathrm{ml}$. Twenty five milliters of agar medium was poured in each dish. Wells were punched in the agar and each filled with $50 \mu 1$ of each tested garlic extract concentration. The plates were then incubated at $4^{\circ} \mathrm{C}$ for $2 \mathrm{hr}$ then incubated for 4 days at $30^{\circ} \mathrm{C}$ and the resulted inhibition zones around the wells were then measured. The well containing the highest dilution (lowest concentration of garlic) that still showed a zone of inhibition around, it was seemed to be the MIC.

Effect of garlic extract on mycelial dry weights and penicillic acid levels of $P$. hirsutum : The modified Raulin-Thom broth was adjusted to $\mathrm{pH} 3$, using varying amounts of $1 \mathrm{~N}$ of both $\mathrm{HCl}$ and $\mathrm{NaOH}$, was transferred to $250 \mathrm{ml}$ Erlenmeyer flasks at $50 \mathrm{ml}$ aliquots and sterilized at $121^{\circ} \mathrm{C}$ for $20 \mathrm{~min}$. Different concentrations of aqueous garlic extracts $(0.0,0.60,1.20,3.00,6.00,12.0,18.0,24.0$, and 30.0 $\mathrm{mg} / \mathrm{ml}$ culture medium) were separately added to the culture medium. The flasks were inoculated with $6.0 \mathrm{~mm}$ of 7-days old $P$. hirsutum culture under aseptic conditions and incubated for 10 days at $25^{\circ} \mathrm{C}$ which are the optimum conditions for maximum penicillic acid production by $P$. hirsutum (Ismaiel, 2007). The fungal cultures were observed visually after $2,4,7$ and 10 days.

\section{Mycelial dry weights}

At the end of the incubation period, the culture flasks were filtered through pre-weighted Whatman no. 1 filter papers, oven-dried at $80^{\circ} \mathrm{C}$ till a constant weight.

Determination of penicillic acid

The amounts of penicillic acid in the culture filtrates were determined quantitatively by the colorimetric method described by Bentley \& Keil (1962) and Wirth \& Klosek (1972) with some modifications. A known volume of the culture filtrate was extracted with equal volume of ethyl acetate, shaked for about $10 \mathrm{~min}$ and allowed to stand for $10 \mathrm{~min}$. The ethyl acetate layer was then separated, dried and evaporated in a water bath at $60^{\circ} \mathrm{C}$. The dried ethyl acetate extract was then dissolved in a known volume of hot water. After cooling, a 3fold excess of concentrated ammonia was added. The resultant reddish purple complex was allowed to develop for $20 \mathrm{~min}$ and the absorbance was measured at $545 \mathrm{~nm}$ with a spectrophotometer (Spectronic Molton Roy Co., 20 D). Meanwhile, penicillic acid production by P.hirsutum was determined qualitatively after spotting on TLC plates with standard penicillic acid (Sigma Chemical Co., Louis St., USA) according to the method described by Ciegler \& Kurtzman (1970) and Aziz \& Moussa (2002). 
Statistical analysis

All experiments were conducted in triplicates and the mean \pm standard deviation (SD) of these triplicates was calculated. The results of antifungal activity tests were analyzed by ANOVA (at 0.05 and 0.01 levels)

\section{Chemical analysis of garlic extract}

A suspension of acetone garlic extract was prepared for the GC-MS analysis, that was carried out in Mass Spectrometry Unit, Central Scientific Services Lab, National Research Centre, Dokki, Cairo, Egypt. $1.0 \mu \mathrm{l}$ of the suspension was injected into GC, model Thermo Trace GC 2000 equipped with MS equipment, model Finnigan SSQ 7000 instrument. The MS is coupled with a DBWAX capillary column $(30 \mathrm{~cm} \times 0.25 \mathrm{~mm}$ internal diameter, film thickness $0.25 \mu \mathrm{m}$ ). The electron impact was $70 \mathrm{ev}$. The injector temperature was programmed at $220^{\circ} \mathrm{C}$ and the column was held at $40^{\circ} \mathrm{C}$ for $3 \mathrm{~min}$ and then programmed to $250^{\circ} \mathrm{C}$ at $5^{\circ} \mathrm{C} / 2 \mathrm{~min}$. The components were identified by comparison of retention indices and mass spectra with those of the standards in the library.

\section{Results and Discussion}

In the present work, a preliminary test was conducted to elucidate the antifungal effect of different concentrations of the aqueous Egyptian garlic extract towards $P$. hirsutum by the agar cup-plate method (Table 1). The size of the inhibition halo was clearly proportional to the concentration of garlic extract applied to each well. It has been found that the MIC of aqueous garlic extract necessary for growth inhibition of $P$. hirsutum, was $30 \mathrm{mg} / \mathrm{ml}$. Various values for MIC of aqueous garlic extract were reported by other authors. Bakri \& Douglas (2005) recorded low value of $8.9 \mathrm{mg} / \mathrm{ml}$ against Candida albicans, while, Irkin \& Korukluoglu (2007) found high MIC of $325 \mathrm{mg} / \mathrm{ml}$ against Aspergillus niger. The susceptibility of many fungi to the antifungal activity of garlic extract was decided by many authors (Trichosporon and Rhodotorula, Tansey \& Appleton, 1975; Torulopsis, Trichophyton and Cryptococcus, Fromtling \& Bulmer, 1978 and Aspergillus, Hitokoto et al., 1980).

The relationship between spore production by $P$. hirsutum in Raulin-Thom broth containing varying concentrations of garlic is summarized in Table 2. After 2 days of incubation, sporulation was very slight at $0.6 \mathrm{mg} / \mathrm{ml}$ and inhibited completely at the higher concentrations. After 4 days of incubation, it was slight at $1.2 \mathrm{mg} / \mathrm{ml}$ and inhibited at 3 to $24 \mathrm{mg} / \mathrm{ml}$. After the extended incubation periods (7-10 days), sporulation became intense at the lower concentrations (0.6 to $3 \mathrm{mg} / \mathrm{ml}$ ), completely inhibited after 7 days of incubation at 18 to $24 \mathrm{mg} / \mathrm{ml}$ and may be also inhibited or very slight at these higher concentrations after 10 days of incubation. Graham \& Graham (1987) showed that the higher concentration of garlic extract $(0.25-0.4 \%)$ inhibited the sporulation of $A$. parasiticus. The inhibition of fungal spores germination may be attributed to the presence of allicin and ajoene (a derivative of allicin) and some essential oils as main components of garlic extract (Naganawa et al., 1996; Yamada \& Azuma, 1997 and Benkeblia, 2004).

Egypt. J. Microbiol. 44 (2009) 
TABLE 1. Relation between concentration of aqueous garlic extract $(\mathrm{mg} / \mathrm{ml})$ and the inhibition zones diameters $(\mathrm{mm})$ of the tested $P$. hirsutum.

\begin{tabular}{|c|c|}
\hline Concentration of garlic extract $\mathbf{( m g / m l})$ & Diameter of inhibition zones $(\mathbf{m m})$ \\
\hline 30 & $7.66 \pm 1.15$ \\
\hline 60 & $8.66 \pm 1.52$ \\
\hline 120 & $11.66 \pm 1.15$ \\
\hline 240 & $14.0 \pm 0.00$ \\
\hline 360 & $18.0 \pm 1.00$ \\
\hline 480 & $18.6 \pm 0.57$ \\
\hline 540 & $19.0 \pm 0.00$ \\
\hline 600 & $21.0 \pm 1.00$ \\
\hline
\end{tabular}

MIC $=30 \mathrm{mg} / \mathrm{ml}$. The results of this Table were analyzed statistically by ANOVA by comparison of the concentrations of aqueous garlic extract $(\mathrm{mg} / \mathrm{ml})$ at the mean values of different diameters of inhibition zones. At 0.05 level, significant values of inhibition zone diameters were obtained in comparison of the concentration either at 30 or $60 \mathrm{mg} / \mathrm{ml}$ with others tested concentrations $(\mathrm{P}<0.05)$. Also, significant values were obtained in comparison of the concentration at $120 \mathrm{mg} / \mathrm{ml}$ with all tested concentrations. The concentration at $240 \mathrm{mg} / \mathrm{ml}$ showed significant values with the concentrations at 360,480 , 540 and $600 \mathrm{mg} / \mathrm{ml}$. Though, the concentration at $360 \mathrm{mg} / \mathrm{ml}$ showed significant values in comparison with the concentration at $600 \mathrm{mg} / \mathrm{ml}$ but no significant values were obtained, as compared with the concentrations either at 480 or $540 \mathrm{mg} / \mathrm{ml}(\mathrm{P}>0.05)$. At the concentration of $480 \mathrm{mg} / \mathrm{ml}$, a significance was obtained, as compared with the concentration at $600 \mathrm{mg} / \mathrm{ml}(\mathrm{P}=0.023)$ however, no significance was obtained, as compared with the concentration at $540 \mathrm{mg} / \mathrm{ml}(\mathrm{P}=0.724)$. At the concentration of $540 \mathrm{mg} / \mathrm{ml}$, a significance was obtained, as compared with the concentration at $600 \mathrm{mg} / \mathrm{ml}$ $(\mathrm{P}=0.047)$. At 0.01 level, high significant values of inhibition zone diameters were obtained in comparison of the concentration either at 30 or $60 \mathrm{mg} / \mathrm{ml}$ with others tested concentrations $(\mathrm{P}<0.01)$. High significant values were obtained in comparison of the concentration at $120 \mathrm{mg} / \mathrm{ml}$ with the concentrations at $360,480,540$ and $600 \mathrm{mg} / \mathrm{ml}$. The concentration at $240 \mathrm{mg} / \mathrm{ml}$ showed high significant values, as compared with the concentrations at $360,480,540$ and $600 \mathrm{mg} / \mathrm{ml}$. High significant values were obtained in comparison of the concentration at $360 \mathrm{mg} / \mathrm{ml}$ with the concentration at $600 \mathrm{mg} / \mathrm{ml}(\mathrm{P}<0.01)$.

TABLE 2. Influence of varying concentrations of aqueous garlic extract on spores production by $P$. hirsutum in Raulin-Thom broth incubated at $25^{\circ} \mathrm{C}$ for different days .

\begin{tabular}{|c|c|c|c|c|}
\hline \multirow{2}{*}{$\begin{array}{c}\text { Concentrations } \\
\text { of garlic extract } \\
(\mathbf{m g} / \mathbf{m l})\end{array}$} & \multicolumn{4}{|c|}{ Spores production (a) } \\
\cline { 2 - 5 } & $\mathbf{2}$ & $\mathbf{4}$ & $\mathbf{7}$ & $\mathbf{1 0}$ \\
\hline 0.00 & + & ++ & ++++ & ++++ \\
\hline 0.60 & + & ++ & ++++ & ++++ \\
\hline 1.20 & - & + & +++ & +++ \\
\hline 3.00 & - & - & +++ & +++ \\
\hline 6.00 & - & - & ++ & ++ \\
\hline 12.0 & - & - & $-(+)$ & + \\
\hline 18.0 & - & - & - & $-(+)$ \\
\hline 24.0 & - & - & - & $-(+)$ \\
\hline
\end{tabular}

$+=$ very slight,$++=$ slight,$+++=$ heavy,$++++=$ very heavy.

Egypt. J. Microbiol. 44 (2009) 
Figure 1 summarizes the effect of different concentrations of garlic extract (the sublethal concentrations less than $30 \mathrm{mg} / \mathrm{ml}$ ) on mycelial dry weights and penicillic acid production by $P$. hirsutum. It was obvious that the average values of mycelial dry weights slightly increased with the increase of garlic concentrations reaching a maximum at $24 \mathrm{mg} / \mathrm{ml}$. Inhibition of mycelial production was essentially complete at a garlic concentration of $30 \mathrm{mg} / \mathrm{ml}$. Similar results were obtained by Graham \& Graham (1987), who showed that apparent stimulation of mycelial production at the lower garlic concentrations was due to the presence of small amounts of nutrients such as minerals and vitamins in the added garlic. The stimulation of mycelial growth at the concentrations less than $30 \mathrm{mg} / \mathrm{ml}$ of garlic extract may be due to the presence of lower amounts of allicin and sulfide compounds in the extract and were insufficient to inhibit or decrease the mycelial growth. These components in garlic extracts are responsible for antifungal activity (Bianchi et al., 1997 and Ankri \& Mirelman, 1999). Removal of allicin from the reaction by solvent extraction decreased the antifungal activity of garlic extract (Hughes \& Lawson, 1991). The contrary was took place for penicillic acid production where the increase in the garlic concentration causes a decrease in the levels of penicillic acid. The amount of penicillic acid produced in the presence of $24 \mathrm{mg} / \mathrm{ml}$ of garlic was approximately $44 \%$ of that produced in the culture control filtrate (free from any garlic extract) after 10 days of incubation. It is worthy to mention that penicillic acid was completely, undetected at a garlic concentration of $24 \mathrm{mg} / \mathrm{ml}$ after 7 days of incubation. Moreover, the fungal mycelial growth and toxin production were inhibited by garlic concentration of $30 \mathrm{mg} / \mathrm{ml}$. Garlic extracts were reported to have an inhibitory effect on aflatoxins production by $A$. parasiticus (Graham \& Graham, 1987 and Lawson, 1996) and keratinase activity in T. mentagrophytes (Ghahfarokhi et al., 2003). The antifungal mode of garlic extracts action were recognized from their capability to decrease oxygen uptake (Szymona, 1952), inhibit the synthesis of lipids, proteins and nucleic acids (Adetumbi et al., 1986), damage membranes (Ghannoum, 1988), collapse the fungal hyphae, increase the number and size of the vacuoles in cells and increase the cell wall thickening (Bianchi et al., 1997).

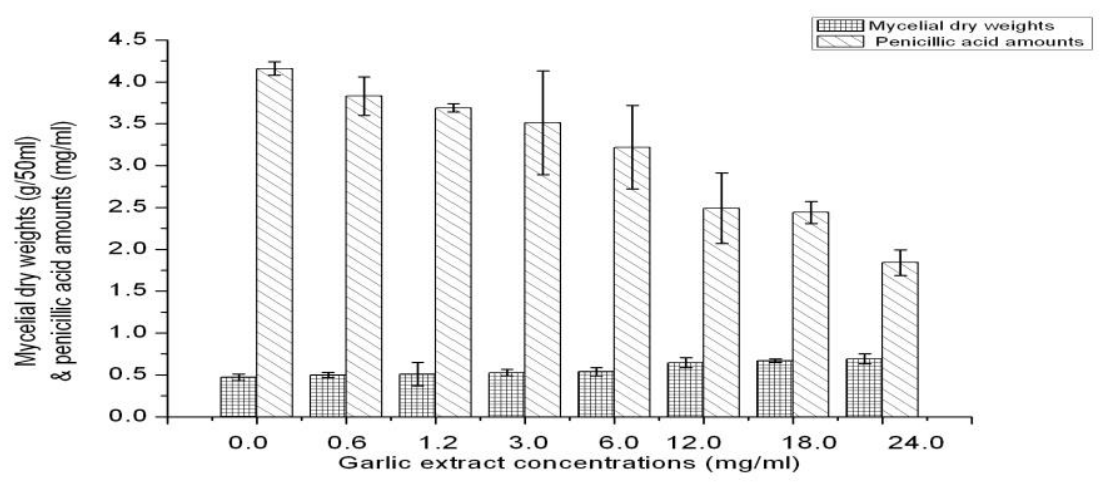

Fig. 1. Influence of varying concentrations of aqueous garlic extract on mycelium dry weights $(\mathrm{g} / 50 \mathrm{ml})$ and penicillic acid levels $(\mathrm{mg} / \mathrm{ml})$ of $P$. hirsutum in Raulin-Thom broth incubated at $25^{\circ} \mathrm{C}$ for 10 days.

Egypt. J. Microbiol. 44 (2009) 
The main components of acetone garlic extract were determined using GC-MS chromatogram analysis as represented in Table 3 and electronically photographed as shown in Fig. 2. It is interest to mention that the garlic extract consists mainly of about 17 components. The major components were quinolinium 1-ethyl-iodide (CAS) (quinoline ethiodide), 60.83\% ; 8, 9, 10, 11- tetrahydrocyclonona [de] naphthalene -7, 12-dione, 5.88\%; trisulfide, methyl-2-propenyl (CAS) (methylallyl trisulfide), $4.88 \%$; benzene, (1.3-daimethyl-3-butenyl)-(CAS) (1-pentene, 2methyl-4-phenyl), $4.54 \%$. The results also indicated that the garlic extract contains less percentages of 3, 4-dihydro-3-vinyl-1.2 dithiin, 3.61\%; 1.2- divinylbenzene, $3.24 \%$ and disulfide, di-2-propenyl (CAS) [1.2-bis (allyl) disulfane], 2.18\%. In this connection, the volatile compounds of suspension of micronized garlic powder were determined using GC-MS analysis and mainly consisted of linear chain of aldehydes, allyl disulfides and disulfides (Bianchi et al., 1997). A concentrated garlic extract containing $34 \%$ allicin, $44 \%$ total thiosulfinates and $20 \%$ vinyldithiins possessed potent in vitro fungistatic and fungicidal activity against three different isolates of C. neoformans (Davis et al., 1994). Allicin (diallyl thiosulfinate), is formed from allin by the action of allinase and gets metabolized rapidly into diallyl sulfide, diallyl disulfide, diallyl trisulfide, ajoene, $S$-allyl mercaptocysteine, $S$-allyl cysteine and dithiines (Welch et al., 1992; Sundaram \& Milner, 1993; Sigounas et al., 1997; Dirsch et al., 1998 and Hirsch et al., 2000). Barone \& Tansey (1977) suggested that the sulfur-reduced compounds present in garlic might act by binding with sulfhydrlic groups of essential amino acids, proteins and enzymes. This study confirms this hypothesis, since the analysis of the garlic extract revealed the presence of some thioalkylating agents that may responsible for the antifungal activity. Most of the biological effects of allicin including its antimicrobial activity can be related to its strong SH-modifying capacity and antioxidant properties (Koch \& Lawson, 1996 and Lawson, 1998).

In conclusion, the results obtained indicate that, garlic extract had inhibitory effects on growth, spore formation and penicillic acid production by $P$. hirsutum. The inhibitory activities of garlic extract were manifested by determination of the main active components applying GC-MS chromatogram analysis which revealed that garlic extract consists of 17 components. The major components were quinoline ethiodide; $8,9,10,11$ - tetrahydrocyclonona [de] naphthalene - 7 , 12-dione; methylallyl trisulfide; 1-pentene,2-methyl-4-phenyl; 3,4-dihydro-3vinyl-1.2dithiin; 1.2-divinylbenzene and 1.2-bis(allyl)disulfane. This study suggests the suitability of garlic extract as a natural and safe additive to food preparations, offering a protection against intoxication from penicillic acid. 
TABLE 3. Main components of acetone garlic extract.

\begin{tabular}{|c|c|c|}
\hline $\begin{array}{l}\text { Retention } \\
\text { time (min) }\end{array}$ & Compounds & Area $(\%)$ \\
\hline 11.35 & $\begin{array}{l}\text { 2-(3-hydroxy-1-oxopropyl)-1.1-1-trimethyl-hydrazinium } \\
\text { hydroxide inner salt }\end{array}$ & 2.20 \\
\hline 15.54 & Phenyl acetylene-2-d & 0.33 \\
\hline 16.41 & 1-hexanol, 2-ethyl-(CAS) & 1.79 \\
\hline 18.10 & Disulfide, di-2-propenyl(CAS) & 2.18 \\
\hline 19.42 & 4-methoxy-1-(2-oxobut-3-enyl) azetidin-2-one & 1.12 \\
\hline 20.07 & Trisulfide, methyl-2-propenyl (CAS) & 4.88 \\
\hline 21.90 & 3.4-Dihydro-3-vinyl-1.2 dithiin & 3.61 \\
\hline 22.65 & $\begin{array}{l}{\left[4 \mathrm{~S}-\left(2 \mathrm{E}, 4 \mathrm{R}^{*}, 5 \mathrm{~S}^{*}, \quad 6 \mathrm{R}^{*}, 7 \mathrm{E}\right)\right]-10 \text {-(benzoyloxy)-5- }} \\
\text { hydroxy- } 4.6 \text {-dimethoxy- } 2.8 \text { dimethyl-2.7-decadienoic } \\
\text { acid methyl ester }\end{array}$ & 3.84 \\
\hline 24.69 & 8-(Trimethylsilyl)-6-octenteneitrile & 2.92 \\
\hline 37.32 & Benzene, [(Fluoromethyl) thiol]-(CAS) & 0.73 \\
\hline 39.43 & $\begin{array}{l}8,9,10,11 \text { - tetrahydrocyclonona }[\mathrm{de}] \text { naphthalene- } 7.12- \\
\text { dione }\end{array}$ & 5.88 \\
\hline 40.01 & Tetradecaoic acid (CAS) & 0.44 \\
\hline 41.16 & Quinolinium, 1-ethyl-, iodide (CAS) & 28.69 \\
\hline 41.52 & Quinolinium, 1-ethyl-, iodide (CAS) & 24.46 \\
\hline 43.32 & Quinolinium, 1-ethyl-, iodide (CAS) & 7.68 \\
\hline 43.96 & 1,2-Divinyl benzene & 3.24 \\
\hline 44.65 & Hexadecanoic acid (CAS) & 0.48 \\
\hline 45.80 & Benzene, (1,3-dimethyl-3-butenyl)-(CAS) & 4.54 \\
\hline 46.22 & (E)- 3,3-diphenyl-4-hexenoic acid & 0.97 \\
\hline Total & & $99.98 \%$ \\
\hline
\end{tabular}


INHIBITORY EFFECT OF EGYPTIAN GARLIC ...

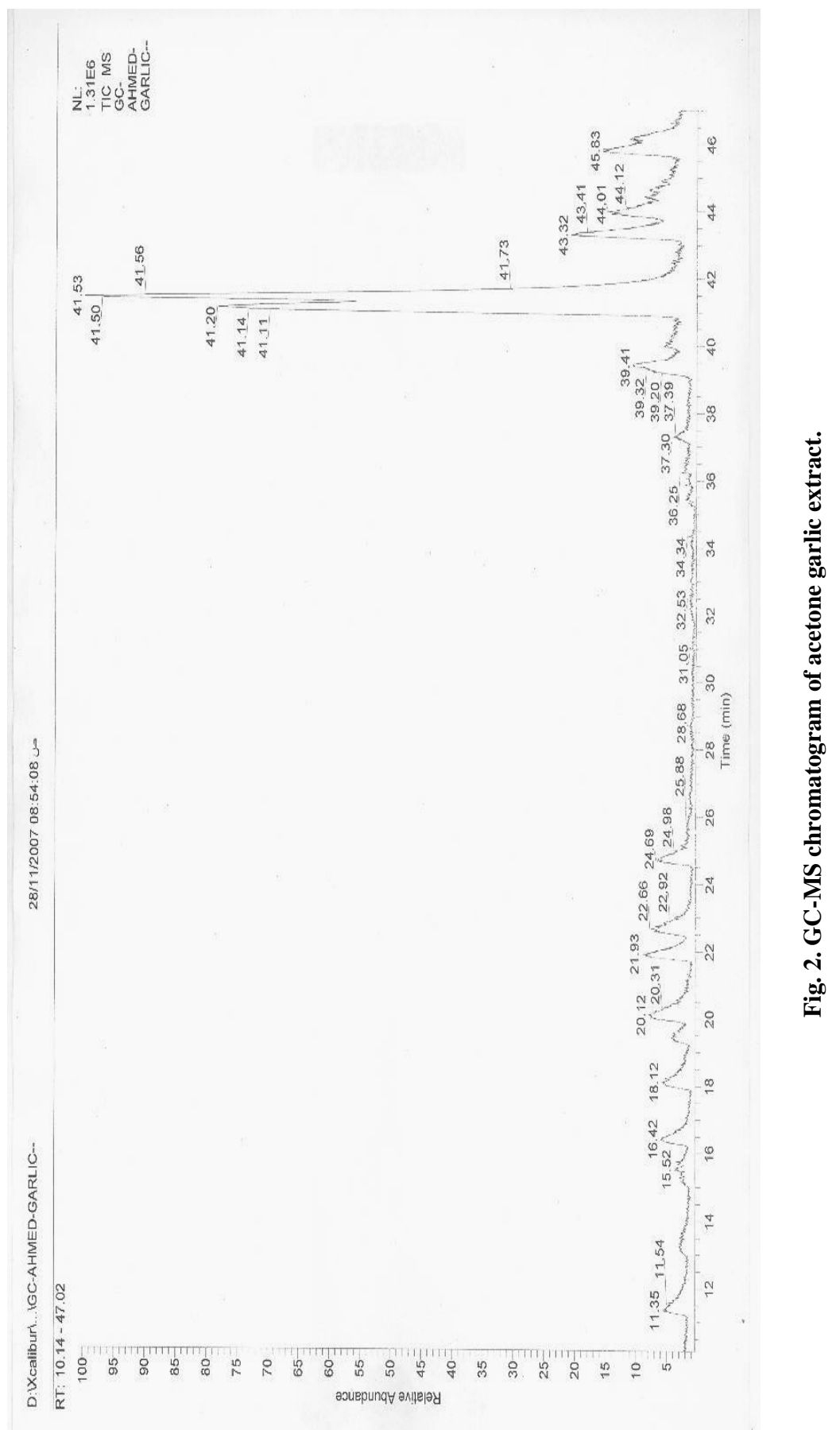

Egypt. J. Microbiol. 44 (2009) 


\section{References}

Adetumbi, M.A., Javor, G.T. and Lau, B.H.S. (1986) Allium sativum (garlic) inhibits lipid synthesis by Candida albicans. Antimicrob. Agents Chemother, 30, 499- 501.

Ankri, S. and Mirelman, D. (1999) Antimicrobial properties of allicin from garlic. Microb. Infec. 2, 125- 129.

Aziz, N.H. and Moussa, L.A.A. (2002) Influence of gamma-radiation on mycotoxin producing moulds and mycotoxins in fruits. Food Control, 13, 281- 288.

Bakri, I.M. and Douglas, C.W.I. (2005) Inhibitory effect of garlic extract on oral bacteria. Arch. Oral Biol. 50, 645- 651.

Barone, F.E. and Tansey, M.R. (1977) Isolation, purification, identification, synthesis and kinetics of activity of the anticandidal component of Allium sativum, and hypothesis for its mode of action. Mycologia , 69, 793- 825 .

Benkeblia, N. (2004) Antimicrobial activity of essential oil extracts of various onions (Allium cepa) and garlic (Allium sativum). Lebensm.-Wiss.u-Technol. 37, 263- 268.

Bentley, R. and Keil, J.G. (1962) Tetronic acid biosynthesis in molds. II. Formation of penicillic acid in Penicillium cyclopium. J. Biol. Chem. 237 (3), 867- 873.

Bianchi, A., Zambonelli, A., D'Aulerio, A.Z. and Bellesia, F. (1997) Ultrastructural studies of the effects of Allium sativum on phytopathogenic fungi in vitro. Plant Disease, 81 (11), 1241- 1246.

Ciegler, A. and Kurtzman, C.P. (1970) Flurodensitometric assay of penicillic acid. $J$. Chr. 51, 511- 516.

Ciegler, A., Mintzlaff, H.J., Weisleder, D. and Leistner, L. (1972) Potential production and detoxification of penicillic acid in mold fermented sausage (Salami). Appl. Microbiol. 24,114-119.

Curtis, H., Noll, U., Störmann, J. and Slusarenko, A. (2004) Broad-spectrum activity of the volatile phytoanticipin allicin in extracts of garlic (Allium sativum L.) against plant pathogenic bacteria, fungi and oomycetes. Physiological and Molecular Plant Path. 65, 79- 89.

Davis, L.E., Shen, J. and Royer, R.E. (1994) In vitro synergism of concentrated Allium sativum extract and amphotericin B against Cryptococcus neoformans. Planta Med. 60, 546-549.

Dirsch, V.M., Gerbes, A.L. and Vollmar, A.M. (1998) Ajoene, a compound of garlic, induces apoptosis in human promyeloleukemic cells, accompanied by generation of reactive oxygen species and activation of nuclear factor kappa B. Mol. Pharmacol. 53, 402- 407.

Ezzat, S.M., El-Sayed, A.E., Abou El-Hawa, M.I. and Ismaiel, A.A. (2007) Morphological and ultrastructural studies for the biological action of penicillic acid on some bacterial species. Res. J. Microbiol. 2 (4), 303- 314.

Egypt. J. Microbiol. 44 (2009) 
Frisvad, J.C. (1981) Physiological criteria and mycotoxin production as aids in identification of common asymmetric penicillia. Appl. Environ. Microbiol. 41, 568579 .

Frisvad, J.C. and Filtenborg, O. (1983) Classification of terverticillate penicillia based on profiles of mycotoxins and other secondary metabolites. J. Chr. 2392, 333- 347.

Frisvad, J.C. and Samson, R.A. (2004) Polyphasic Taxonomy of Penicillium Subgenus Penicillium. A Guide to identification of Food and Air-Borne Terverticillate Penicillia and their Mycotoxins. In: "Penicillium Subgenus Penicillium: New Taxonomic Schemes, Mycotoxins and other Extrolites". Robert A. Samson and Jens C. Frisvad (Ed.), Studies in Mycology No. 49, pp, 1- 174.

Fromtling, R.A. and Bulmer, G.S. (1978) In vitro effect of aqueous garlic extract (Allium sativum) on the growth and viability of Cryptococcus neoformans. Mycologia, 70, 397- 405.

Garza, S., Canela, R., Vinas, I. and Sanchis, V. (1993) Effects of potassium sorbate on growth and penicillic acid production by Aspergillus ochraceus and Penicillium aurantiogriseum. Zentralbl. Mikrobiol. 148 (5), 343- 350.

Ghahfarokhi, M.S., Razafsha, M., Allameh, A. and Abyaneh, M.R. (2003) Inhibitory effects of aqueous onion and garlic extracts on growth and keratinase activity in Trichophyton mentagrophytes. Iran Biomed. J. 7, 113- 118.

Ghannoum, M.A. (1988) Studies on the anticandicidal mode of action of Allium sativum (garlic). J. Gen. Microbiol. 134, 2917- 2924.

Gourama, H. and Bullerman, L.B. (1988) Mycotoxin production by molds isolated from "Greek-style" black olives. Int. J. Food Microbiol. 6, 81- 90.

Graham, H. D. and Graham, E.J.F. (1987) Inhibition of Aspergillus parasiticus growth and toxin production by garlic. J. Food Safety, 8, 101- 108.

Haciseferogullari, H., Özcan, M., Demir, F. and Calisir, S. (2005) Some nutritional and technological properties of garlic (Allium sativum L.). J. Food Eng. 68, 463- 469.

He, J., Wijerantne, E.M.K., Bashyal, B.P., Zhan, X.J., Seliga, C.J., Liu, M.X., Pierson, E.E., Pierson, L.S. III, Van Etten, H.D. and Gunatilaka, A.A.L. (2004) Cytotoxic and other metabolites of Aspergillus inhibiting the rhizosphere of Sonoran desert plants. J. Nat. Prod. 67, 1985- 1991.

Hirsch, K., Danilenko, M., Giat, J., Miron, T., Robinkov, A., Wilchek, M., Mirelman, D., Levy, J. and Sharon, Y. (2000) Effect of Purified allicin, the major ingredient of freshly crushed garlic, on cancer cell proliferation. Nutr. Cancer, 38, 245- 254.

Hitokoto, H., Morozumi, S., Wauke, T., Sakai, S. and Kurata, H. (1980) Inhibitory effects of spices on growth and toxin production of toxigenic fungi. Appl. Environ. Microbiol. 39, 818- 822. 
Hughes, B.G. and Lawson, L.D. (1991) Antimicrobial effects of Allium sativum L. (garlic) Allium ampeloprasum (elephant garlic) and Allium cepa L. (onion) garlic compounds and commercial garlic supplement products. Phtother. Res. 5,154-158.

Irkin, R. and Korukluoglu, M. (2007) Control of Aspergillus niger with garlic, onion and leek extracts. African J. Biotechnol. 6 (4), 384- 387.

Ismaiel, A.A. (2007) Effect of acidic microbial toxins on morphology and ultrastructures of bacteria. Ph.D. Thesis, Faculty of Science, Zagazig Univ., Egypt.

Koch, H.P. and Lawson, L.D. (1996) "Garlic: The Science and Therapeutic Application of Allium sativum L. and Related Species", Williams and Wilkins, Baltimore.

Kurtzman, C.P. and Ciegler, A. (1970) Mycotoxin from a blue-eye mold of corn. Appl. Microbiol. 20, 204- 207.

Lari, J. and Thomas, R. (1980) Selective inhibition of the biosynthesis of penicillic acid. Tetrahedron, 36, 3305- 3307.

Lawson, L.D. (1996) The composition and chemistry of garlic covers and processed garlic. In: "Garlic: The Science and Therapeutic Application of Allium sativum L." , Koch, H.P., Lawson, L.D. (Ed.), pp. 37-108. Williams and Wilkins, Baltimore.

Lawson, L.D. (1998) Garlic: a review of its medicinal effects and indicated active compounds, In: "Phytomedicines of Europe: their Chemistry and Biological Activity", L.D. Lawson, R. Bauer (Ed.), pp. 176- 209. American Society, Washington.

Lindenfelser, L.A. and Ciegler, A. (1977) Penicillic acid production in submerged culture. Appl. Environ. Microbiol. 34 (5) , 553- 556.

Macri, A., Dancea, Z. and Baba, A.I. (2002) Mycotoxin involvement in oncogenesis: bibliographical investigations. Buletinul Universitii de Stiinte Agricole si Medicina Veterinara Cluj Nopoca Seria Medicina Veterinara. 58, 640- 644.

Naganawa, R., Iwata, N., Ishikawa, K., Fukuda, H., Fujino, T. and Suzuki, A. (1996) Inhibition of microbial growth by ajoene, a sulfur containing compound derived from garlic. Appl. Environ. Microbiol. 62, 4238- 4242.

Onyeagba, R.A., Ugbogu, O.C., Okeke, C.U. and Iroakasi, O. (2004) Studies on the antimicrobial effects of garlic (Allium sativum Linn), ginger (Zingiber officinale Roscoe) and lime (Citrus aurantiofolia Linn). Afr. J. Biotechnol. 3, 552- 554.

Overy, D.P., Frisvad, J.C., Steinmeier,U. and Thrane, U. (2005) Clarification of the agents causing blue mold storage rot upon various flower and vegetable bulbs; implication for mycotoxin contamination. Postharvest Biol. Technol. 35, 217- 221.

Palmgren, M.S. and Ciegler, A. (1983) Toxicity and carcinogenicity of fungal lactones: Patulin and penicillic acid. "Handbook of Natural Toxins" Volume 1. plant and fungal toxins , pp. 325- 341 .

Pero, R.Q., Harven, D., Owens, R.G. and Snow, J.P. (1972) A gas chromatographic method for the mycotoxin penicillic acid. J. Chr. 65, 501- 506.

Egypt. J. Microbiol. 44 (2009) 
Satio, M., Rai, D.R. and Masuda, R. (2004) Isolation of Penicillium hirsutum from spoiled, packaged asparagus spears in Japan. J. Gen. Plant Path. 69 (5), 304- 306.

Sigounas, G., Hooker, J., Anagnostou, A. and Stiener, M. (1997) $S \_a l l y l m e r$ captocysteine inhibits cell proliferation and reduces the viability of erythroleukemia, breast, and prostate cancer cell lines. Nutr. Caner , 27, 186-191.

Sundaram, S.G. and Milner, J.A. (1993) Impact of organosulfur compounds in garlic on canine mammary tumor cells in culture. Cancer Lett. 74, 85- 90.

Szymona, M. (1952) Effect of phytoncides of Allium sativum on the growth and respiration of some pathogenic fungi. Acta Microbial. Pol. 1, 5- 23.

Tansey, M.R. and Appleton, J.A. (1975) Inhibition of fungal growth by garlic extract. Mycologia , 67, 409- 413.

Tariq, V.N. and Magee, A.C. (1990) Effect of volatiles from garlic bulb extract on Fusarium oxysporum f. sp. lycopersici. Mycol. Res. 94 (5), 617- 620.

Thrope, C.W. and Jhonson, R. L. (1974) Analysis of penicillic acid by gas-liquid chromatography. J. Assoc. Off. Anal. Chem. 57, 861- 865.

Wannemacher, R.W., Bunner, J. and Neufeld, H.A. (1991) Toxicity of trichothecenes and other related mycotoxins in laboratory animals. "Mycotoxins and Animal Foods", pp. 499-552.

Welch, C., Wuarin, L. and Sidell, N. (1992) Antiproliferative effect of the garlic compound $S$-allyl cysteine on human neuroblastoma cells in vitro. Cancer Lett. 63, 211- 219 .

Wirth, J. and Klosek, R. (1972) Fungi: Moniliales: Relationships in Penicillium aurantiovirens. Phytochem. 11, 2615.

Yamada, Y. and Azuma, K. (1997) Evaluation of the in vitro antifungal activity of allicin. Antimicrob. Agents Chemother. 11, 743- 749.

Yoshida, A.S., Kasuga, S., Hayashi, N., Ushiroguchi, T., Matsuura, H. and Nakagawa, S. (1987) Antifungal activity of ajoene derived from garlic. Appl. Environ. Microbiol. 53, 615- 617.

( Received 29/5/2008; accepted 1/12/2008) 


\section{التأثير المثبط لمستخلص الثوم المصرى على إنتاج السم الفطرى حض البنسيليك \\ أحمد عبد الرحمن إسماعيل \\ قسم النبات - كلية العلوم - جامعة الزقازيق - الزقازيق - مصر.}

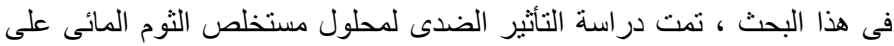

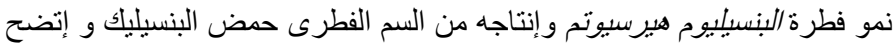

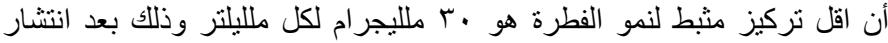

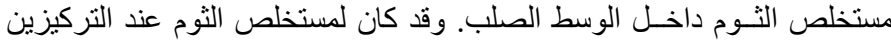

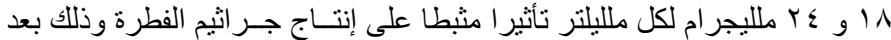

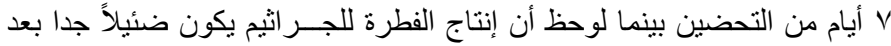

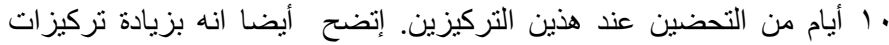

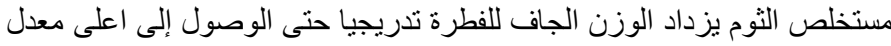

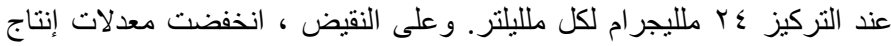

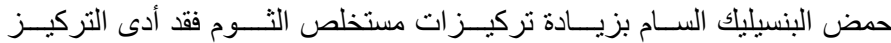

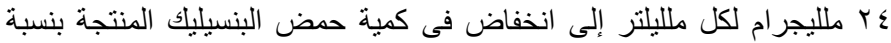

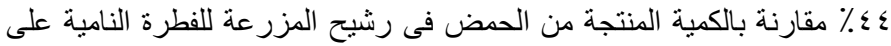

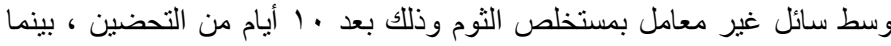

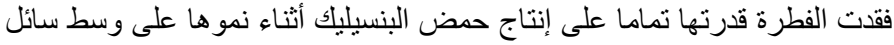
يحتوى على نفس التركيز من مستخلص الثوم بعد التحضين لمدة V أيام.

إمتد هذا البحث إلى عمل دراسة تحليلية لتعيين وتقييم نسب المركبات الأساسية

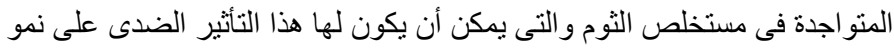

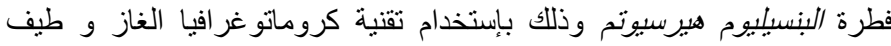

